\title{
Research on the Allocation Efficiency and Influencing Factors of Scientific and Technological Resources in the Yangtze River Delta City Group
}

\author{
Yuhong H. Cao ${ }^{1}$, Jianxin X. You ${ }^{2}$, Yongjiang J. Shi ${ }^{3}$ and Wei Hu ${ }^{4, *}$ \\ 1 School of Management, Shanghai University, Shanghai 200444, China; caoyuhong@shu.edu.cn \\ 2 School of Economics \&Management, Tongji University, Shanghai 200092, China; yjx2256@tongji.edu.cn \\ 3 Institute for Manufacturing, University of Cambridge, Cambridge CB3 0FS, UK; ys@eng.cam.ac.uk \\ 4 School of Economics and Trade, Shanghai Urban Construction Vocational College, Shanghai 201999, China \\ * Correspondence: huwei@succ.edu.cn
}

check for updates

Citation: Cao, Y.H.; You, J.X.; Shi, Y.J.; Hu, W. Research on the Allocation Efficiency and Influencing Factors of Scientific and Technological Resources in the Yangtze River Delta City Group. Sustainability 2021, 13, 7951. https://doi.org/10.3390/ su13147951

Academic Editor: João Carlos de Oliveira Matias

Received: 18 May 2021

Accepted: 12 July 2021

Published: 16 July 2021

Publisher's Note: MDPI stays neutral with regard to jurisdictional claims in published maps and institutional affiliations.

Copyright: (c) 2021 by the authors. Licensee MDPI, Basel, Switzerland. This article is an open access article distributed under the terms and conditions of the Creative Commons Attribution (CC BY) license (https:/ / creativecommons.org/licenses/by/ $4.0 /)$.

\begin{abstract}
Through the establishment of a comprehensive evaluation index system, this paper analyzes the allocation of science and technology resources in the Yangtze River Delta urban agglomeration from 2014 to 2020, evaluates the allocation efficiency of science and technology resources from the perspective of multi input and output, and understands the advantages and disadvantages of regional resource allocation. The research results show that: (1) under the guidance of the national strategic policy of actively promoting the development of world-class urban agglomerations, the allocation efficiency of science and technology resources in various provinces and cities of the Yangtze River Delta continues to optimize, and the allocation level of some regions shows a rapid development trend; (2) R\&D personnel and R\&D funds are the core factors that affect the efficiency of science and technology resource allocation; (3) the marketization of resource allocation is helpful to improve its allocation efficiency; and (4) improving the transformation rate of scientific and technological achievements, opening up the channel for innovative products, technologies, and services to enter the market, and enabling innovative enterprises to make profits can provide strong and lasting incentives for the improvement of scientific and technological resource allocation efficiency. Based on the research conclusions, this paper puts forward countermeasures and suggestions to improve the allocation efficiency of scientific and technological resources in the Yangtze River Delta urban agglomeration from the aspects of human resources and material resources, and provides a theoretical reference for the coordinated and sustainable development of the Yangtze River Delta City Group under the background of the implementation of the urban agglomeration strategy and the construction of a scientific and technological infrastructure platform.
\end{abstract}

Keywords: Yangtze River Delta city group; allocation of science and technology resources; efficiency evaluation and optimization

\section{Introduction}

Urban agglomeration is a new model for promoting the interactive development of regional sectors. Its establishment has become an important strategic way for countries to develop productivity and optimize production factors. According to the development law of the world's urban agglomerations, when the urbanization level exceeds $30 \%$, the urban agglomerations will enter a period of rapid development, and the rapid development needs a lot of resources, especially scientific and technological resources as support [1]. The contribution of science and technology resources to urban agglomerations has a multiplier effect, which is the source of internal power and strength for urban agglomerations. To a certain extent, its allocation efficiency determines the advantages and disadvantages of regional science and technology innovation ability [2,3]. At present, there are great differences in resource elements among different regions in China [4], and there is also a big 
gap in the allocation of science and technology resources. This gap not only accelerates the expansion of the economic and social gaps, but also destroys the coordinated development of different regions. To this end, it is necessary to study and evaluate the efficiency of regional science and technology resource allocation and its differences.

The Yangtze River Delta urban agglomeration is an important part of China's economic development urban agglomeration, and it is also a core area that promotes the country's urban economic development. With the development of the international economy and social changes, scientific and technological resources have become one of the major strategic resources for the economic development of the region. Its allocation optimization and the improvement of scientific and technological innovation ability have become the primary demand of regional science and technology management and collaborative development. At present, the allocation of science and technology resources in the Yangtze River Delta urban agglomeration has a prominent imbalance, such as unequal input and output of resources, uneven geographical distribution, etc., which directly affects the innovation ability and overall technological competitiveness of the urban agglomeration in the Yangtze River Delta [5]. Therefore, it is necessary to correctly understand the current situation of the current allocation of science and technology resources in the Yangtze River Delta city group, and summarize the scale, distribution, and structure characteristics of the existing allocation of science and technology resources, as well as the law of multi-interval temporal and spatial evolution. For this reason, this study takes four provinces and cities of the Yangtze River Delta as the research object; through the analysis of the change trend and related analysis of the input and output of science and technology resources in each province, compares the efficiency of scientific and technological resources allocation in order to further understand the regional gap of the efficiency of the allocation of science and technology resources in the four provinces and cities of the city group; and then determines the crux of the gap and provides the basis for seeking solutions. The research will be of great practical significance to alleviate the pressure of science and technology investment, improve the ability of science and technology innovation and competitiveness, and promote the coordinated development of the Yangtze River Delta.

In the aspect of the efficiency of science and technology resource allocation, many scholars have carried out a lot of quantitative research using different research methods. Liu [6], Huang [7], and Cao et al. [8], based on the research of Fare et al. [9], combined with the DEA Malmquist index model and random effect model, conducted an empirical test on the changes of allocation efficiency of science and technology resources and its influencing factors in China. Based on the construction of the evaluation index system of regional allocation efficiency of science and technology resources, Fan [10] measured the efficiency of science and technology resource allocation in 31 provinces and cities in China by using the mutation series method. Luo et al. [11] evaluated the efficiency of green technology innovation in China based on the Malmquist-data envelope analysis index. Kang [12] used three single evaluation methods: principal component analysis, Entropy TOPSIS, and super efficiency DEA to rank the regional science and technology resource allocation efficiency of 31 provinces and autonomous regions in China, and then used the combination evaluation method to make up for the shortcomings of the single method. $\mathrm{Wu}$ et al. [13] used the Cobb Douglas production function and canonical correlation analysis method to measure the behavior of science and technology resource allocation in the Pan Pearl River Delta region from 1999 to 2007 from the perspective of input-output. Xia and Le [14] used the SBM model and the Global Malmquist index method to measure the efficiency of China's science and technology resource allocation, and pointed out that the efficiency of China's science and technology resource allocation is slowing down in dynamic growth. Under the background of internal circulation construction, intellectual patent protection measures should be strengthened, market development of innovation achievements should be vigorously promoted, and scientific and technological innovation and institutional innovation should be carried out simultaneously. Shu [15] analyzed the basic characteristics of the allocation of science and technology resources in Beijing, Tianjin, 
and Hebei from the scale, distribution, and structure characteristics of the allocation of science and technology resources. Strengthening the dynamic mechanism of the spatial allocation of science and technology resources is the key to avoiding the internal loss of science and technology resources, which is conducive to the efficient development of urban agglomerations in the global resource shortage environment.

The existing research methods on the allocation efficiency of regional science and technology resources mainly include a mathematical economics analysis method, time series data or cross-section data analysis method, and panel data random effect model analysis method [16-18]. The time series data and cross-section data analysis methods mainly include the data envelopment analysis method, production economy function calculation method, and econometric regression analysis method. Under the background of implementing the development strategy of world-class urban agglomerations and the construction plan of scientific and technological infrastructure platform, the innovation of this research lies in the evaluation and analysis of the allocation of scientific and technological resources of four provinces and cities in the Yangtze River Delta Urban Agglomerations from 2014 to 2020 by using the comprehensive evaluation and analysis method of large regional data processing with reference to the relevant research in $\mathrm{Li}$ [19]. Through the establishment of a comprehensive evaluation index system, according to the principle of consistency with the strategic objectives of regional economic and social development, the relative development level of the main scientific and technological resources input index and output index of the four provinces and cities is solved, and then on the basis of comparative analysis, the scientific suggestions of resource allocation optimization are put forward.

\section{Comprehensive Evaluation of the Allocation Efficiency of Science and Technology Resources in the Yangtze River Delta Urban Agglomeration}

The comprehensive evaluation method, also known as the multi-index comprehensive evaluation method, refers to the use of more systematic and normative methods to evaluate multiple indexes and multiple units at the same time. It is the general name of a series of methods adopted for comprehensive evaluation of multiple indexes. This evaluation method is mainly based on the establishment of the evaluation index system of the research object, with the help of relevant methods or models, to analyze the collected data, so as to implement quantitative and overall judgment on the evaluated things. The characteristics of the comprehensive evaluation method are as follows: first, the evaluation process is not completed by one index successively followed by another, but by some special methods to realize the simultaneous evaluation of multiple indexes; second, in the process of comprehensive evaluation, we should implement weighted treatment according to the importance of indicators to ensure that the evaluation results are more scientific; third, the evaluation results are ranked according to the comprehensive score, and the corresponding conclusions are obtained. Using the comprehensive evaluation method to evaluate the allocation efficiency of science and technology resources in the Yangtze River Delta urban agglomeration can not only realize the comprehensive analysis of the allocation of science and technology resources, but also realize the timely search for potential problems. At the same time, the application of the comprehensive evaluation method can effectively avoid the impact of human factors on the evaluation of resource allocation efficiency and ensure that the obtained data and related analysis are more accurate. The evaluation process of this study includes three steps: first, the evaluation index system is set up based on reference to the existing evaluation index system of the allocation efficiency of scientific and technological resources and expert suggestions; secondly, the mean square error decisionmaking method is used to determine the weight coefficient of each index; and finally, the method of multi-index decision-making ranking is used for a comprehensive evaluation.

\subsection{Indicator Setting}

Considering the scientific nature, reliability, continuity, and availability of index data, and the statistical scope of the China Statistical Yearbook and China Science and 
Technology Statistics Yearbook, this research constructed a scientific and technological resources allocation efficiency indicator system based on the existing evaluation index system, as shown in Tables 1 and 2.

A total of 39 statistical indicators were selected for the study, and two first-level indicators of scientific and technological resource input and scientific and technological resource output were set up. The input indicators of scientific and technological resources were divided into three secondary indicators of scientific and technological human resources, scientific and technological financial resources, and scientific and technological material resources, and 23 three-level indicators. The output index of science and technology resources was divided into five secondary indexes of patents, papers, works, standards, and economic growth, and 16 three-level indicators. The statistical period was from 2014 to 2020, with a total of 7 consecutive years of continuous collection, with a total of 1092 data items. The data mainly come from the Shanghai Science and Technology Statistical Yearbook (2014-2020), Jiangsu Science and Technology Statistical Yearbook (2014-2020), Zhejiang Science and Technology Statistical Yearbook (2014-2020), and Anhui Science and Technology Statistical Yearbook (2014-2020).

\subsection{Data Processing}

In order to solve the problem of the inconsistent dimensions of indicators, the study adopts the range method to normalize the comparison matrix, construct the judgment matrix, and standardize the original data. Suppose the scheme set in the multi-index comprehensive evaluation problem is $S=\left\{S_{1}, S_{2}, \ldots, S_{n}\right\}$ and the index set is $D=\left\{D_{1}, D_{2}, \ldots, D_{n}\right\}$, then the attribute value of scheme $S_{i}$ to index $D_{j}$ is $x_{i j}(i=1,2, \ldots, n ; j=1,2, \ldots, m)$, and $X=\left(x_{i j}\right)_{n * m}$ represents the decision matrix of scheme set $S$ to index set $D$

$$
\begin{aligned}
y_{i j}=\left\{\begin{array}{c}
\left(x_{i j}-x_{j \min }\right) /\left(x_{j \max }-x_{j \min }\right) \\
\left(x_{i j}-x_{j \max }\right) /\left(x_{j \max }-x_{j \min }\right)
\end{array}\right\} . \\
i=1,2, \ldots, n ; j=1,2, \ldots, m
\end{aligned}
$$

where $y_{i j}$ is the standardized data, $x_{\max }$ and $x_{\min }$ respectively represent the maximum and minimum values of the index $D_{j}$, and the matrix obtained after processing is the decision matrix.

All indicators in the index system selected in this article are positive indicators. The larger the standardized $y_{i j}$ value, the greater the positive effect displayed. 
Table 1. Scientific and technological resources input indicators and their weights (2014-2020).

\begin{tabular}{|c|c|c|c|c|c|c|c|c|c|}
\hline & \multirow{2}{*}{$\begin{array}{l}\text { First Level } \\
\text { Indicators }\end{array}$} & \multirow{2}{*}{ Second Level Indicators } & \multicolumn{7}{|c|}{ Weight } \\
\hline & & & 2014 & 2015 & 2016 & 2017 & 2018 & 2019 & 2020 \\
\hline \multirow{21}{*}{$\begin{array}{l}\text { Evaluation } \\
\text { indicators of } \\
\text { science and } \\
\text { technology } \\
\text { resources input }\end{array}$} & \multirow{7}{*}{$\begin{array}{l}\text { Human } \\
\text { resources of } \\
\text { science and } \\
\text { technology }\end{array}$} & 1. Total number of R\&D personnel/person & 0.5674 & 0.5562 & 0.5597 & 0.5481 & 0.5509 & 0.5316 & 0.5228 \\
\hline & & 2. Number of R\&D personnel in enterprises above designated size/person & 0.1891 & 0.1854 & 0.1865 & 0.1827 & 0.1836 & 0.1772 & 0.1743 \\
\hline & & 3. Number of R\&D personnel in high-tech industry/person & 0.2114 & 0.2013 & 0.2216 & 0.2203 & 0.2166 & 0.2308 & 0.2154 \\
\hline & & $\begin{array}{l}\text { 4. Number of R\&D personnel in colleges and universities and scientific } \\
\text { research institutions/person }\end{array}$ & 0.1669 & 0.1695 & 0.1516 & 0.1451 & 0.1507 & 0.1236 & 0.1331 \\
\hline & & $\begin{array}{l}\text { 5. The total number of R\&D personnel full-time equivalent/ten } \\
\text { thousand people }\end{array}$ & 0.4326 & 0.4438 & 0.4403 & 0.4519 & 0.4491 & 0.4684 & 0.4772 \\
\hline & & 7. Full time R\&D equivalent of high-tech industry/ten thousand people & 0.1568 & 0.1606 & 0.1596 & 0.1668 & 0.1632 & 0.1663 & 0.1706 \\
\hline & & $\begin{array}{l}\text { 8. Full time R\&D equivalent of colleges and universities and scientific research } \\
\text { institutions/ten thousand people }\end{array}$ & 0.1316 & 0.1353 & 0.1339 & 0.1345 & 0.1362 & 0.1460 & 0.1475 \\
\hline & \multirow{8}{*}{$\begin{array}{l}\text { Financial } \\
\text { resources of } \\
\text { science and } \\
\text { technology }\end{array}$} & 9. R\&D expenditure/ten thousand yuan & 0.4091 & 0.4122 & 0.4014 & 0.3918 & 0.4115 & 0.4142 & 0.4317 \\
\hline & & 10. R\&D expenditure of enterprises above designated size/ten thousand yuan & 0.1363 & 0.1374 & 0.1338 & 0.1306 & 0.1372 & 0.1381 & 0.1439 \\
\hline & & 11. High-tech industry R\&D expenditure/ten thousand yuan & 0.1625 & 0.1563 & 0.1572 & 0.1601 & 0.1598 & 0.1606 & 0.1682 \\
\hline & & $\begin{array}{l}\text { 12. R\&D expenditure of colleges and universities and scientific research } \\
\text { institutions/ten thousand yuan }\end{array}$ & 0.1103 & 0.1185 & 0.1104 & 0.1011 & 0.1145 & 0.1155 & 0.1196 \\
\hline & & 14. Government funds in R\&D expenditure/ten thousand yuan & 0.1204 & 0.1124 & 0.1095 & 0.1022 & 0.1125 & 0.1156 & 0.1132 \\
\hline & & 15. Enterprise funds in R\&D expenditures/ten thousand yuan & 0.1248 & 0.1182 & 0.1237 & 0.1286 & 0.1304 & 0.1292 & 0.1255 \\
\hline & & $\begin{array}{l}\text { 16. Expenditures for new product development and technology introduction of } \\
\text { enterprises above designated size/ten thousand yuan }\end{array}$ & 0.0904 & 0.1013 & 0.0992 & 0.1008 & 0.1115 & 0.1108 & 0.0991 \\
\hline & & $\begin{array}{l}\text { 17. Expenditures for new product development and technology introduction of } \\
\text { high-tech industries/ten thousand yuan }\end{array}$ & 0.1187 & 0.1278 & 0.1358 & 0.1545 & 0.1074 & 0.0955 & 0.1029 \\
\hline & \multirow{6}{*}{$\begin{array}{c}\text { Material } \\
\text { resources of } \\
\text { science and } \\
\text { technology }\end{array}$} & $\begin{array}{l}\text { 18. Number of colleges and universities and scientific research } \\
\text { institutions/individual }\end{array}$ & 0.2013 & 0.1934 & 0.1968 & 0.2125 & 0.1962 & 0.2069 & 0.1947 \\
\hline & & $\begin{array}{l}\text { 19. Number of R\&D institutions of enterprises above designated } \\
\text { size/individual }\end{array}$ & 0.1667 & 0.1524 & 0.1493 & 0.1638 & 0.1557 & 0.1613 & 0.1582 \\
\hline & & 20. Number of high-tech industry R\&D institutions/individual & 0.1885 & 0.1762 & 0.1873 & 0.1864 & 0.1897 & 0.1741 & 0.1856 \\
\hline & & $\begin{array}{l}\text { 21. Number of projects undertaken by colleges and universities and scientific } \\
\text { research institutions/piece }\end{array}$ & 0.2123 & 0.2319 & 0.2254 & 0.1967 & 0.2146 & 0.2232 & 0.2083 \\
\hline & & $\begin{array}{l}\text { 22. Number of projects undertaken by R\&D institutions of enterprises above } \\
\text { designated size/piece }\end{array}$ & 0.1076 & 0.1108 & 0.1122 & 0.1031 & 0.1069 & 0.1123 & 0.1264 \\
\hline & & $\begin{array}{l}\text { 23. Number of projects undertaken by high-tech industry R\&D } \\
\text { institutions/piece }\end{array}$ & 0.1236 & 0.1353 & 0.1290 & 0.1375 & 0.1369 & 0.1222 & 0.1268 \\
\hline
\end{tabular}


Table 2. Scientific and technological resources output index and their weights (2014-2020).

\begin{tabular}{|c|c|c|c|c|c|c|c|c|c|}
\hline & \multirow{2}{*}{$\begin{array}{l}\text { First Level } \\
\text { Indicators }\end{array}$} & \multirow{2}{*}{ Second Level Indicators } & \multicolumn{7}{|c|}{ Weight } \\
\hline & & & 2014 & 2015 & 2016 & 2017 & 2018 & 2019 & 2020 \\
\hline \multirow{15}{*}{$\begin{array}{l}\text { Evaluation } \\
\text { index of } \\
\text { scientific and } \\
\text { technological } \\
\text { resources } \\
\text { output }\end{array}$} & \multirow{6}{*}{ Patent } & 24. Number of patent applications/piece & 0.2126 & 0.2254 & 0.2379 & 0.2313 & 0.2342 & 0.2321 & 0.2367 \\
\hline & & 25. Number of patent applications for high-tech industry/piece & 0.1058 & 0.1116 & 0.1125 & 0.1179 & 0.1131 & 0.1122 & 0.1187 \\
\hline & & $\begin{array}{l}\text { 26. Number of patent applications of industrial enterprises above designated } \\
\text { size/piece }\end{array}$ & 0.1068 & 0.1138 & 0.1254 & 0.1134 & 0.1211 & 0.1199 & 0.1180 \\
\hline & & 27. Number of patents granted/piece & 0.2313 & 0.2291 & 0.2113 & 0.2136 & 0.2154 & 0.2093 & 0.2016 \\
\hline & & 28. Patent ownership transfer and licensing income/ten thousand yuan & 0.2568 & 0.2612 & 0.2635 & 0.2679 & 0.2644 & 0.2673 & 0.2669 \\
\hline & & 29. Technology market turnover/Ten thousand yuan & 0.2993 & 0.2843 & 0.2873 & 0.2872 & 0.2860 & 0.2913 & 0.2948 \\
\hline & \multirow[t]{2}{*}{ Paper } & $\begin{array}{l}\text { 30. Number of scientific and technological papers published by universities } \\
\text { and scientific research institutions/piece }\end{array}$ & 0.6234 & 0.6365 & 0.6417 & 0.6382 & 0.6391 & 0.6373 & 0.6452 \\
\hline & & $\begin{array}{l}\text { 31. Number of scientific and technological papers published by high-tech } \\
\text { industry and industrial enterprises above designated size/piece }\end{array}$ & 0.3766 & 0.3635 & 0.3583 & 0.3618 & 0.3609 & 0.3627 & 0.3548 \\
\hline & \multirow[t]{2}{*}{ Literary work } & $\begin{array}{l}\text { 32. Number of scientific and technological works published by universities and } \\
\text { scientific research institutions/volume }\end{array}$ & 0.6634 & 0.6412 & 0.6543 & 0.6609 & 0.6614 & 0.6568 & 0.6619 \\
\hline & & $\begin{array}{l}\text { 33. Number of scientific and technological works published by high-tech } \\
\text { industry and industrial enterprises above designated size/piece }\end{array}$ & 0.3366 & 0.3588 & 0.3457 & 0.3391 & 0.3386 & 0.3432 & 0.3381 \\
\hline & \multirow{2}{*}{ Standard } & 34. Number of national standards/piece & 0.5637 & 0.5669 & 0.6012 & 0.6138 & 0.5935 & 0.5877 & 0.5655 \\
\hline & & 35. Number of industry standards/piece & 0.4363 & 0,4331 & 0.3988 & 0.3862 & 0.4065 & 0.4123 & 0.4345 \\
\hline & \multirow{3}{*}{$\begin{array}{l}\text { Export and total } \\
\text { output value }\end{array}$} & 37. Total export commodities/ten thousand yuan & 0.2135 & 0.2167 & 0.2158 & 0.2136 & 0.2176 & 0.2234 & 0.2173 \\
\hline & & 38. Export value of high-tech products/ten thousand yuan & 0.2334 & 0.2365 & 0.2298 & 0.2311 & 0.2357 & 0.2286 & 0.2308 \\
\hline & & 39. Industrial output value of high-tech industries/ten thousand yuan & 0.2898 & 0.2852 & 0.2990 & 0.2962 & 0.2843 & 0.2827 & 0.2878 \\
\hline
\end{tabular}




\subsection{Method for Determining Indicator Weight}

Then, the mean square error decision-making method was used to determine the weight coefficient of each indicator. This method calculates the standardized mean square error of each indicator and normalizes it. The result is the weight of each indicator. The calculation formula is as follows:

$$
\begin{aligned}
& \text { Mean value of random variable : } M\left(D_{i}\right)=\frac{1}{n} \sum_{i=1}^{n} y_{i j} \\
& \text { Mean square error : } \delta\left(D_{i}\right)=\sqrt{\sum_{i=1}^{n}\left(y_{i j}-M\left(D_{i}\right)\right)^{2}} \\
& \text { Index } D_{j} \text { weight coefficient : } \omega_{j}=\delta\left(D_{i}\right) / \sum_{j=1}^{m} \delta\left(D_{i}\right)
\end{aligned}
$$

The calculation results of index weights are shown in Tables 1 and 2.

\subsection{Comprehensive Evaluation Results of Science and Technology Resources Allocation in the Yangtze River Delta Urban Agglomeration}

After the evaluation index weight was determined, the multi-index decision-making ranking method was used for comprehensive evaluation. The calculation formula is:

$$
E_{i}(\omega)=\sum_{j=1}^{m} y_{i j} \omega_{i}
$$

According to Formula (5) and the weight of comprehensive evaluation indicators in Tables 1 and 2, all 39 indicators of urban science and technology resource allocation of each province in the urban agglomeration from 2014 to 2020 are processed. This paper only list

\begin{tabular}{|c|c|c|c|c|c|c|c|c|c|c|c|c|c|c|}
\hline \multirow{2}{*}{ Province } & \multicolumn{2}{|c|}{2014} & \multicolumn{2}{|c|}{2015} & \multicolumn{2}{|c|}{2016} & \multicolumn{2}{|c|}{2017} & \multicolumn{2}{|c|}{2018} & \multicolumn{2}{|c|}{2019} & \multicolumn{2}{|c|}{2020} \\
\hline & Input & Output & Input & Output & Input & Output & Input & Output & Input & Output & Input & Output & Input & Output \\
\hline Shanghai & 0.439 & 0.896 & 0.531 & 0.864 & 0.665 & 0.897 & 0.718 & 0.922 & 0.791 & 0.943 & 0.804 & 1.032 & 0.851 & 0.997 \\
\hline Jiangsu & 0.332 & 0.653 & 0.407 & 0.699 & 0.417 & 0.743 & 0.538 & 0.809 & 0.667 & 0.887 & 0.711 & 0.898 & 0.756 & 0.892 \\
\hline Zhejiang & 0.329 & 0.612 & 0.394 & 0.641 & 0.408 & 0.738 & 0.539 & 0.796 & 0.659 & 0.833 & 0.694 & 0.835 & 0.719 & 0.854 \\
\hline Anhui & 0.248 & 0.508 & 0.385 & 0.594 & 0.393 & 0.744 & 0.403 & 0.798 & 0.598 & 0.846 & 0.696 & 0.851 & 0.708 & 0.868 \\
\hline
\end{tabular}
the comprehensive evaluation results of each province in each year (see Table 3 ).

Table 3. Comprehensive evaluation results of science and technology input and output of four provinces in the Yangtze River Delta urban agglomeration from 2014 to 2020.

\section{Analysis of Comprehensive Evaluation Results of Scientific and Technological Resources Allocation Efficiency}

\subsection{Overall Analysis}

According to Table 3 and the data calculated by the four provinces and cities' scientific and technological statistical yearbooks, it was found that: (1) in the past seven years, Shanghai ranked first in the total score of comprehensive evaluation, and the level of science and technology input and output ranked first. As a pilot area of the national innovation driven development strategy, in the past seven years, with the support of governments at all levels, in addition to the total amount of science and technology resources having been greatly improved, its allocation efficiency has also been rapidly improved. Statistics show that in 2014, nearly $70 \%$ of the R\&D funds in Shanghai were invested in traditional industries, while only slightly more than $30 \%$ were in high-tech fields. In 2020 , these two data were $40 \%$ and $60 \%$, respectively. This change has significantly enhanced the driving role of Shanghai's high-tech industry, with an average annual growth rate of $31.4 \%$ in the added value of the high-tech industry, which is higher than that of all industries 
above the designated size by $11.4 \%$. (2) Jiangsu Province ranked second in the total score of the comprehensive evaluation, and the level of technological input and technological output ranked second. Jiangsu Province took the lead in the country in 1989 to propose the implementation of the "Science and Technology Prosperity" strategy. In the past seven years, the investment in science and technology has increased significantly. In 2014, the total R\&D investment in the whole society accounted for $2.1 \%$ of the regional GDP. By 2020 , the total R\&D investment in the whole society accounted for $2.8 \%$ of the regional GDP. Several scientific and technological fields reached the world's leading level, and the contribution rate of scientific and technological progress to economic growth reached more than $65 \%$. It has become a strategic highland for national independent innovation and an industrial technological innovation center with important global influence. (3) Anhui Province ranked third in the total score of the comprehensive evaluation, with its technology input level ranking fourth and its technology output level ranking third. After seven years of hard work, important progress has been made in the reform of the science and technology system in Anhui province, and the environment for innovation and entrepreneurship has been increasingly optimized. By 2020, R\&D investment in the whole society accounted for $3.2 \%$ of the regional GDP, laying a solid foundation for the accelerated release of technological and talent advantages. (4) Zhejiang Province ranked fourth in the total score of the comprehensive evaluation, and its science and technology input level ranked third, while its science and technology output level ranked fourth. In 2020, the R\&D investment of the whole society accounted for $2.3 \%$ of the GDP, the independent innovation capability of enterprises has been significantly improved, and the R\&D platform system has also been improved. At the same time, the proportion of local large and medium-sized enterprises with R\&D institutions has doubled, and the output of knowledge innovation has increased significantly.

From the perspective of investment, the investment level of science and technology resources in the four provinces and cities shows a rapid growth trend as a whole, as shown in Figure 1. At the beginning of 2014, the comprehensive evaluation results of the four provinces and municipalities' investment indicators for science and technology resources were as follows: Shanghai 0.439, Zhejiang 0.392, Jiangsu 0.332, and Anhui 0.248. At the end of 2020, the evaluation results from high to low were 0.951 in Shanghai, 0.756 in Jiangsu, 0.719 in Zhejiang, and 0.708 in Anhui. In terms of the growth rate and the level of resource input, Shanghai was the largest and was in a fully leading position, and the position of stably ranking the first has not changed. Jiangsu, Zhejiang, and Anhui are increasing rapidly, especially Anhui Province, which fully reflects the strong influence of implementing the strategic policy of science and technology leading development of the Yangtze River Delta urban agglomeration. The gap in the overall input level of the four provinces and cities gradually decreased. At the beginning of the evaluation in 2014, the input level was distributed in the range of $0.2-0.5$, and in 2020 it was distributed in the range of 0.7-0.9. Comparing Anhui with Shanghai, the level of investment in science and technology resources in Anhui in 2014 was only 56.5\% of Shanghai's, and by 2020 it was equivalent to $74.44 \%$ of Shanghai's, and the gap in investment levels has narrowed significantly. Since the evaluation weights of the same year are the same, the evaluation results of the same year are comparable to the level of resource input. 




Figure 1. Comprehensive evaluation momentum of science and technology resources input level of four provinces and cities from 2014 to 2020.

From the perspective of output, Shanghai had obvious advantages, Jiangsu and Zhejiang maintained a relatively uniform growth, while Anhui Province had an obvious growth momentum. The change trend of the output level of science and technology resources in the four provinces and cities is shown in Figure 2. At the beginning of 2014, the comprehensive evaluation results of output indicators were 0.719 in Shanghai, 0.612 in Zhejiang, 0.653 in Jiangsu, and 0.508 in Anhui. At the end of 2020, the evaluation results were 0.997 in Shanghai, 0.892 in Jiangsu, 0.868 in Anhui, and 0.854 in Zhejiang. The gap between the overall output level of the four provinces and cities is narrowing. Similarly, compared with Shanghai, Anhui's science and technology resources output level in 2014 was only $70.6 \%$ of Shanghai's, and it rose rapidly to $87.1 \%$ of Shanghai's by 2020 , and the later output level surpassed Zhejiang's.

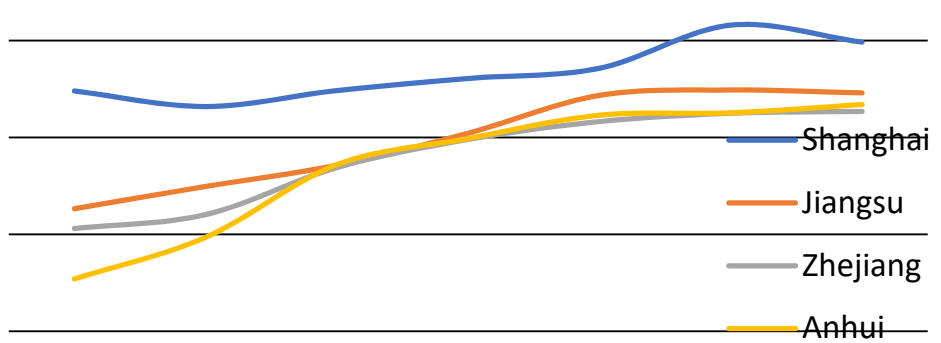

Figure 2. Comprehensive evaluation momentum of science and technology resources output level of four provinces and cities from 2014 to 2020.

\subsection{Analysis of Core Indicators}

To facilitate the analysis, this study selected eight core indicators from 23 threelevel indicators of science and technology resources input as the basis for factor impact evaluation, as shown in Table 4. The starting point for the selection of these eight core indicators was that in addition to considering the weight, it was also necessary to take into account the coordination of the parties in the process of resource allocation, in order to find out the direction of follow-up improvement more accurately and effectively. 
Table 4. Comprehensive evaluation average value of secondary indicators of science and technology resources input from 2014 to 2020 .

\begin{tabular}{|c|c|c|c|c|c|c|c|c|}
\hline Province & $\begin{array}{c}\text { Total } \\
\text { Number of } \\
\text { R\&D } \\
\text { Personnel }\end{array}$ & $\begin{array}{c}\text { The Total } \\
\text { Number of } \\
\text { R\&D } \\
\text { Personnel } \\
\text { Full-Time } \\
\text { Equivalent }\end{array}$ & $\begin{array}{l}\text { R\&D Ex- } \\
\text { penditure }\end{array}$ & $\begin{array}{l}\text { Proportion } \\
\text { of R\&D } \\
\text { Expendi- } \\
\text { ture in } \\
\text { GDP }\end{array}$ & $\begin{array}{l}\text { Government } \\
\text { Funds in } \\
\text { R\&D Ex- } \\
\text { penditure }\end{array}$ & $\begin{array}{l}\text { Enterprise } \\
\text { Funds in } \\
\text { R\&D } \\
\text { Expendi- } \\
\text { tures }\end{array}$ & $\begin{array}{c}\text { Total Number of } \\
\text { Three Types of } \\
\text { Scientific } \\
\text { Research } \\
\text { Institutions }\end{array}$ & $\begin{array}{c}\text { Total Number of } \\
\text { Projects } \\
\text { Undertaken by } \\
\text { Three Types of } \\
\text { Scientific } \\
\text { Research } \\
\text { Institutions }\end{array}$ \\
\hline Shanghai & 0.775 & 0.796 & 0.812 & 0.763 & 0.789 & 0.891 & 0.765 & 0.806 \\
\hline Jiangsu & 0.556 & 0.582 & 0.679 & 0.664 & 0.607 & 0.659 & 0.616 & 0.699 \\
\hline Zhejiang & 0.529 & 0.593 & 0.661 & 0.658 & 0.585 & 0.678 & 0.643 & 0.618 \\
\hline Anhui & 0.457 & 0.423 & 0.493 & 0.547 & 0.594 & 0.603 & 0.525 & 0.621 \\
\hline
\end{tabular}

From Table 4, it can be seen that Shanghai was in the leading position in the overall investment level, followed by Jiangsu, Zhejiang, and Anhui provinces. Among the eight investment indicators, Shanghai ranked in the leading position, with especially the R\&D personnel, R\&D expenditure, and the level of government investment and enterprise investment being far higher than other regions.

In the other three provinces, the order of personnel input level was Jiangsu, Zhejiang, and Anhui. The order of total R\&D expenditure level was Zhejiang, Jiangsu, and Anhui. The level of government investment in R\&D was Jiangsu, Anhui, and Zhejiang in turn. The investment level of enterprises in R\&D funds was Zhejiang, Jiangsu, and Anhui in turn. The level of scientific research expenditure of enterprises was in the order of Jiangsu, Anhui, and Zhejiang. The number of R\&D institutions was in the order of Jiangsu, Zhejiang, and Anhui. The number of R\&D projects undertaken was in the order of Jiangsu, Anhui, and Zhejiang. Overall evaluation shows that Jiangsu Province and Zhejiang Province had their own advantages. Jiangsu Province had advantages in R\&D personnel, government investment level in R\&D funds, enterprise scientific research expenditure, and the number of R\&D projects undertaken. Zhejiang Province had advantages in total R\&D expenditure, enterprise investment in R\&D funds, and the number of R\&D institutions. Although Anhui province did not have an advantage in various indicators, it had a very outstanding performance in the number of $R \& D$ projects. The rapid growth in recent years shows that the scientific research vitality is strong, which is closely related to the strong attention and support of Anhui government in recent years.

The dynamic changes of the eight core investment indicators also show certain regional differences. Take the total number of $R \& D$ personnel full-time equivalent as an example. The full-time equivalent of R\&D personnel is shown in Figure 3, and Shanghai was also in the first interval with absolute advantage, and the full-time investment state was stable at the level of 0.92. Zhejiang and Jiangsu were in the second range of 0.79 . Anhui province had the largest increase, from 0.2 to 0.8 . This indicator reflects that the policy of scientific and technological personnel in the Yangtze River Delta urban agglomeration is relatively strong.

The average value of the comprehensive evaluation level of scientific and technological resource output is shown in Table 5 (choose eight secondary indicators as example).

Shanghai had an absolute advantage in the leading position of the Yangtze River Delta urban agglomeration. Among the other three provinces, the number of patent applications was Jiangsu, Anhui, and Zhejiang in order from high to low. Anhui, Zhejiang, and Jiangsu were the first to publish scientific and technological papers and publish scientific and technological works from high to low. The order of obtaining standards was Jiangsu, Anhui, and Zhejiang. The sales volume of new products of enterprises was equal in Zhejiang, Jiangsu, and Anhui. Among the two indexes of patent transfer, license income and technology market transaction volume, Anhui Province had obvious advantages. To some extent, this shows that the technology market of Anhui Province is relatively perfect, which is closely related to the positive promotion of the transformation of technological achievements in Anhui Province in the last two years. 
It can be seen that the input-output level of science and technology resources in Shanghai was in the absolute leading position in the Yangtze River Delta urban agglomeration. Zhejiang and Jiangsu had obvious advantages. Anhui Province had a rapid growth, in which R\&D expenditure was relatively high, and government funding was relatively strong, reflecting the high degree of marketization of resource allocation. There was a significant positive correlation between high input level and high output level in the four provinces.

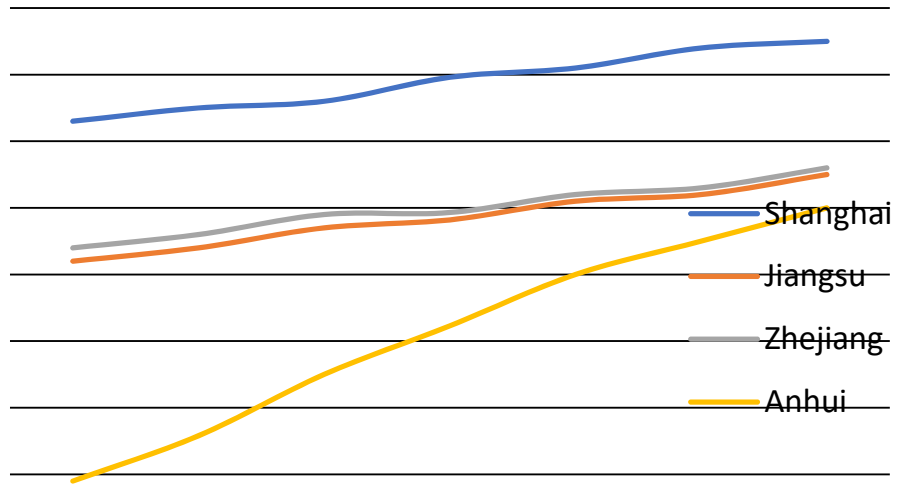

Figure 3. Full-time equivalents of R\&D personnel.

Table 5. Average value of comprehensive evaluation of secondary indicators of science and technology resources output from 2014 to 2020 .

\begin{tabular}{|c|c|c|c|c|c|c|c|c|}
\hline Province & $\begin{array}{c}\text { Number } \\
\text { of Patent } \\
\text { Applica- } \\
\text { tions }\end{array}$ & $\begin{array}{c}\text { Patent } \\
\text { Ownership } \\
\text { Transfer and } \\
\text { Licensing } \\
\text { Income }\end{array}$ & $\begin{array}{c}\text { Technology } \\
\text { Market } \\
\text { Turnover }\end{array}$ & $\begin{array}{c}\text { Number of } \\
\text { Scientific and } \\
\text { Technological } \\
\text { Papers Published by } \\
\text { Universities and } \\
\text { Scientific Research } \\
\text { Institutions }\end{array}$ & $\begin{array}{c}\text { Number of } \\
\text { Scientific and } \\
\text { Technological } \\
\text { Works Published } \\
\text { by Universities } \\
\text { and Scientific } \\
\text { Research } \\
\text { Institutions }\end{array}$ & $\begin{array}{c}\text { Number } \\
\text { of } \\
\text { National } \\
\text { or } \\
\text { Industry } \\
\text { Standards }\end{array}$ & $\begin{array}{c}\text { New } \\
\text { Product } \\
\text { Output } \\
\text { Value }\end{array}$ & $\begin{array}{c}\text { Industrial } \\
\text { Output } \\
\text { Value of } \\
\text { High-Tech } \\
\text { Industries }\end{array}$ \\
\hline Shanghai & 0.833 & 0.792 & 0.763 & 0.836 & 0.858 & 0.765 & 0.773 & 0.729 \\
\hline Jiangsu & 0.595 & 0.491 & 0.468 & 0.575 & 0.547 & 0.597 & 0.457 & 0.456 \\
\hline Zhejiang & 0.557 & 0.404 & 0.459 & 0.593 & 0.496 & 0.551 & 0.463 & 0.418 \\
\hline Anhui & 0.571 & 0.473 & 0.485 & 0.599 & 0.593 & 0.564 & 0.449 & 0.482 \\
\hline
\end{tabular}

The dynamic changes of output indicators also showed large regional differences. For instance, in technology market turnover, the transaction volume of the technology market was the main response to the degree of activity in the regional technology market, as shown in Figure 4. Shanghai's technology market transaction volume was absolutely leading in the Yangtze River Delta region, reaching the upper limit of the comprehensive evaluation score. Before 2016, Jiangsu Province was in a relatively high position with an evaluation score of 0.4-0.7, Zhejiang's was 0.3-0.6, and Anhui's was 0.2-0.4. Starting in 2017, Anhui grew rapidly, and the level in 2020 exceeded 0.6.

\subsection{Input and Output Efficiency Analysis}

This study reflects the efficiency of input and output of science and technology resources in the form of average annual growth rate of indicators. The calculation results are shown in Table 6. 


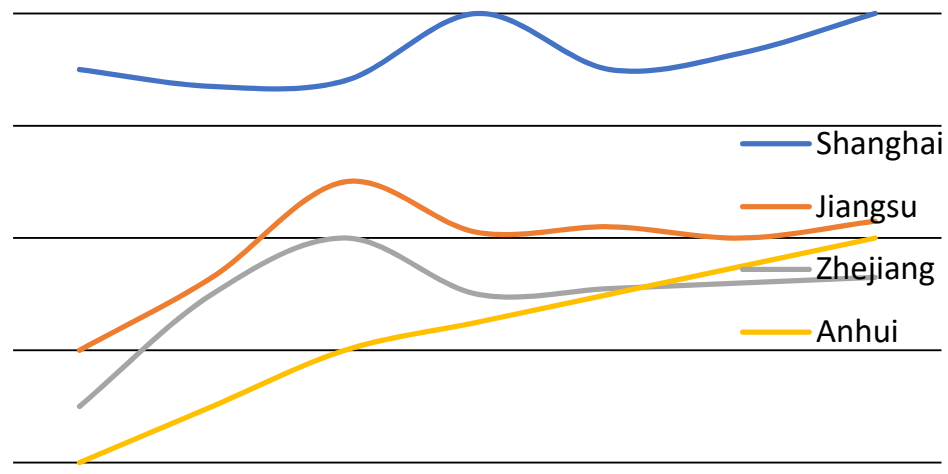

Figure 4. Technology market turnover.

Among the indicators of science and technology human resources, the average annual growth rate of the total $\mathrm{R} \& \mathrm{D}$ personnel in the four provinces and cities was $6.88 \%$, and the largest growth rate was $7.72 \%$ in Jiangsu Province. The average annual growth rate of R\&D personnel in industrial enterprises above designated size was $3.31 \%$, and the biggest increase was $4.16 \%$ in Jiangsu Province. The average annual growth rate of R\&D personnel in high-tech industry was $4.86 \%$, Shanghai was 5.66\%, ranking first, Anhui was $5.32 \%$, slightly higher than Zhejiang and Jiangsu, ranking second. The average annual growth rate of R\&D personnel in colleges and universities and R\&D institutions was $18.02 \%$. Shanghai still ranked first with a growth rate of $20.96 \%$, Anhui Province ranked second with a growth rate of $17.99 \%$, and Zhejiang ranked last with a growth rate of $16.93 \%$. The average annual growth rate of the total R\&D personnel was $11.86 \%$, the highest growth rate being $14.88 \%$ in Shanghai and $10.33 \%$ in Zhejiang. In terms of the change of R\&D personnel growth rate, Shanghai ranked first in the Yangtze River Delta urban agglomeration with the highest absolute value, and Anhui Province ranked second with a significant increase in the numbers indicator. This indicator reflects the promotion effect of human resource policies, which shows that human resource policies in four provinces and cities are active and effective, especially in Anhui Province, where government departments have invested a lot in attracting R\&D talents.

In the indicators of science and technology financial resources, the average annual growth rate of the total R\&D expenditure of the Yangtze River Delta urban agglomeration was $12.23 \%$, and the growth rate of all the provinces and cities was more than $11 \%$, with the highest growth rate being $13.53 \%$ in Jiangsu Province and the lowest growth rate being $11.14 \%$ in Zhejiang Province. In R\&D expenditure, the average annual growth rate of government funds was 3.93\%, the largest growth rate was $4.66 \%$ in Shanghai, followed by $4.23 \%$ in Anhui Province, 3.72\% in Jiangsu Province, and 3.11\% in Zhejiang Province. In R\&D expenditure, the average annual growth rate of enterprise capital was $5.29 \%$, with the highest growth rate of 5.99\% in Anhui Province, 5.82\% in Shanghai, $4.72 \%$ in Zhejiang Province, and $4.66 \%$ in Jiangsu Province. In the index of R\&D expenditure of enterprises, the expenditure of new product development and technology introduction of enterprises above designated size was compared with that of new product development and technology introduction of high-tech industries. The average annual growth rate of new product development and technology introduction expenditure of enterprises above designated size was $12.39 \%$, with the largest increase of $13.42 \%$ in Anhui Province, followed by $12.56 \%$ in Zhejiang Province, $12.34 \%$ in Jiangsu Province, and $11.25 \%$ in Shanghai. The average annual growth rate of R\&D expenditure on new products in high-tech industries 
was $9.63 \%$, followed by $10.32 \%$ in Jiangsu, $9.88 \%$ in Anhui, $9.22 \%$ in Shanghai, and $9.13 \%$ in Zhejiang.

In the indicators of science and technology material resources, the average annual growth rate of R\&D institutions of enterprises above designated size was $13.62 \%$, with the largest growth rate of $15.55 \%$ in Shanghai, and $14.96 \%$ in Jiangsu Province which ranked second. The average annual growth rate of R\&D institutions in high-tech industries was $16.27 \%$, with the largest growth rate of $17.32 \%$ being in Jiangsu Province, followed by $16.56 \%$ in Shanghai, and Zhejiang being in last place in both indicators.

Among the output indicators of science and technology resources, the number of patent applications in the Yangtze River Delta urban agglomeration had an average annual growth rate of $10.74 \%$, with the highest growth rate of $13.32 \%$ in Shanghai, followed by $10.09 \%$ in Jiangsu, Anhui and Zhejiang were similar. The average annual growth rate of the number of patents granted was $7.61 \%$, with the highest growth rate being $9.32 \%$ in Shanghai and $7.33 \%$ in Jiangsu. The average annual growth rate of technology market turnover was $4.71 \%$. Shanghai ranked first with 5.88\%, followed by Anhui Province with $4.72 \%$, and Jiangsu Province and Zhejiang Province with $4.54 \%$ and $3.69 \%$, respectively. The average annual growth rate of new product output value was $2.61 \%$, with the highest growth rate of 3.28\% in Shanghai, 2.79\% in Jiangsu, 2.22\% in Anhui, and $2.15 \%$ in Zhejiang. The average annual growth rate of high-tech products export was $7.16 \%$, with Shanghai ranking first with $7.97 \%$, Anhui ranking second with $7.35 \%$, and Zhejiang ranking fourth with $6.46 \%$. The average annual growth rate of the total industrial output value of high-tech industries was $8.84 \%$, with the highest growth rate of $9.65 \%$ in Shanghai and $8.03 \%$ in Zhejiang. Shanghai was still far ahead of other areas in publishing papers and books, with an increase of more than $9 \%$.

Compared with the average annual growth rate of all the input-output indicators, Shanghai was the fastest growing city in the Yangtze River Delta. The growth rate of various indicators in Jiangsu Province was relatively stable. Anhui Province had a significant growth rate, in terms of $R \& D$ personnel growth and $R \& D$ expenditure in government funds, R\&D institutions of industrial enterprises above designated size, R\&D institutions of high-tech industries, number of patent applications, and export volume of new products of high-tech industries, showing sufficient development potential, which is closely related to the government's active financial and policy investment. Zhejiang Province's R\&D personnel growth rate, government funds in $R \& D$ expenditure, enterprise funds in $R \& D$ expenditure, the number of invention patents authorized, and the export volume of new products in high-tech industries were lower than the average level. 
Table 6. Average growth rate of input and output indicators of science and technology resources from 2014 to 2020.






\section{Conclusions and Recommendations}

The comprehensive evaluation results used in this paper were only used for comparative analysis. Through the comprehensive evaluation of the four provinces and cities' scientific and technological resources allocation efficiency from 2014 to 2020, the following conclusions can be formed.

\section{(1) Regional differences}

The allocation efficiency of science and technology resources in Shanghai is obviously better than that in other provinces. On the one hand, the total amount of science and technology resources input of each subject is much higher than that in other regions. On the other hand, the optimization of various main input measures, such as the attention to the full-time equivalent of the total amount of R\&D personnel, especially the rapid increase of scientific research institutions and projects, has greatly improved the output level.

The allocation efficiency of science and technology resources in Jiangsu and Zhejiang is continuously optimized, and the overall allocation efficiency level shows a trend of continuous improvement. Compared with Jiangsu Province, the efficiency of resource allocation in Zhejiang Province has been improved gently. Due to the geographical advantages, the number of R\&D personnel and full-time equivalent in Zhejiang is equal to that in Jiangsu as a whole, but the investment of each main body lags slightly. It was found that in 2020, affected by the epidemic, the overall R\&D investment in Zhejiang fell more significantly.

In recent years, the allocation efficiency of science and technology resources in Anhui Province has grown rapidly, surpassing Zhejiang Province in many output indicators, such as the total number of patents and their transformation. The relevant government departments have invested great attention, not only with financial support, but also vigorously promoting the construction of all kinds of R\&D institutions.

\section{(2) Optimization policy}

First, R\&D indicators, such as R\&D personnel and the number of R\&D projects, play an important role in the allocation efficiency of science and technology resources. These indicators have a high positive correlation with multiple output indicators such as the number of patent applications output by scientific and technological resources, the export volume, and the volume of technological market transactions. All these indicators are the core element of the government to optimize the efficiency of allocation of scientific and technological resources.

Second, the enterprise funds in $R \& D$ expenditure, scientific research expenditure of high-tech industry, scientific research expenditure of industrial enterprises above designated size and other input indicators, as well as new product sales, patent trading income, technology market turnover, and other output indicators easily show large amplitude fluctuations, which indicates that the allocation of science and technology resources is affected by market changes. Therefore, we should constantly improve the policy environment of regional science and technology resources allocation, improve the system that is conducive to the decisive role of the market, and give full play to the function of government service and guidance, so as to promote the market allocation of science and technology resources more smoothly.

Third, there is a big difference between the growth rate of output indicators such as new product sales, patent transaction income, technology market turnover, and output indicators such as the number of patent applications, the number of patent authorizations, and the number of invention patent authorizations. The number of various patent applications and patent authorizations increased significantly, but the transformation rate of scientific and technological achievements is not high, and a large number of patents have not been applied in practice, which leads to the innovation income being less than the innovation investment, and seriously hinders the innovation power of innovation subjects. In addition to the introduction of policies to enhance patent transformation results, various innovation 
incentive policies also need to be improved to provide strong and lasting incentives for innovation activities.

Fourth, enterprise funds and high-tech industry research funds in R\&D expenditure have increased to a certain extent in the four provinces and cities, but still need to be vigorously promoted. By opening up the channels for innovative products, technologies, and services to enter the market, innovative enterprises can make profits in the market, which can stimulate the increase of R\&D investment of enterprises to a certain extent.

Fifth, a cross-regional allocation mechanism for scientific and technological resources should be established. The Yangtze River Delta urban agglomeration already possesses the overall innovative strength, and a regional scientific and technological development collaborative platform composed of administrative departments and professional technical departments can be established to effectively promote the homogeneous allocation of resource elements and facilitate the flow of resources between cities. At the same time, it is also possible to establish a mechanism for the transfer and transformation of R\&D results across regions, build channels for rapid information sharing and results transformation between regions, and stimulate the internal vitality of the enterprise.

Author Contributions: Conceptualization, Y.H.C.; Data curation, W.H.; Methodology, Y.J.S.; Resources, J.X.Y.; Supervision, Y.J.S.; Writing-original draft, Y.H.C. All authors have read and agreed to the published version of the manuscript.

Funding: This research was funded by The National Natural Science Foundation of China (No.71871134), Planning of Shanghai Soft Science (No.18692104400), and Scientific research projects of School of management of Shanghai University (No.2020-SDGY-KZ-005).

Institutional Review Board Statement: Not applicable.

Informed Consent Statement: Not applicable.

Data Availability Statement: Not applicable.

Conflicts of Interest: The authors declare no conflict of interest.

\section{References}

1. Zhang, Z.H.; Jiao, B.B.; Li, Y. Research on the innovation driven development path in the regions with scarce science and technology resources. Sci. Res. Manag. 2018, 39, 46-59.

2. Luo, S.; An, N. The current situation, problems and Countermeasures of science and technology resources allocation in the Pan Pearl River Delta region. Sci. Res. Manag. 2007, 28, 181-187.

3. Kwon, D.S.; Cho, J.H.; Sohn, S.Y. Comparison of technology efficiency for CO2 emissions reduction among European countries based on DEA with decomposed factors. J. Clean. Prod. 2017, 151, 109-120. [CrossRef]

4. Xia, W.F.; Li, B.Z.; Yin, S. Identification of Influencing Factors for Sustainable Development: Evaluation and Management of Regional Innovation Performance in Heilongjiang, China. Sustainability 2020, 12, 2739. [CrossRef]

5. Yang, T.R.; Ye, M.H.; Pei, P.; Shi, Y.J.; Pan, H.Z. City Branding Evaluation as a Tool for Sustainable Urban Growth: A Framework and Lessons from the Yangtze River Delta Region, China. Sustainability 2019, 11, 4281. [CrossRef]

6. Liu, L.L. Measurement of allocation efficiency of science and technology resources in China. Stat. Decis. Mak. 2008, 24, 47-50.

7. Huang, H.X.; Zhang, Z.H. Research on the allocation efficiency of science and technology resources of strategic emerging industries based on DEA model. China Soft Sci. 2015, 30, 150-159.

8. Cao, L.; Zhou, Z.B.; Wu, Y. Is metabolism in all regions of China performing well: Evidence from a new DEA-Malmquist productivity approach. Ecol. Indic. 2019, 10, 1-15. [CrossRef]

9. Fare, R.; Grosscopf, S.; Lovell, C.A.K. Productivity change in Swedish pharmacies 1980-1989: A nonparametric Malmquist approach. J. Product. Anal. 1992, 3, 81-97. [CrossRef]

10. Fan, F.; Du, D.B.; Li, H. Analysis on allocation efficiency and comparative advantage of regional science and technology resources. Sci. Sci. Res. 2012, 30, 1198-1205.

11. Luo, Q.L.; Miao, C.L.; Sun, L.Y. Efficiency evaluation of green technology innovation of China's strategic emerging industries: An empirical analysis based on Malmquist-data envelopment analysis index. J. Clean. Prod. 2019, 23, 1-10. [CrossRef]

12. Kang, N.; Zheng, X.G.; Mu, P.S. Research on the allocation efficiency of regional science and technology resources in China based on combinatorial evaluation. J. Huazhong Univ. Sci. Technol. 2009, 23, 79-83.

13. Wu, X.J.; Chen, Z. An Empirical Study on the allocation of science and technology resources in Pan Pearl River Delta region. Sci. Technol. Prog. 2010, 27, 52-54.

14. Xia, Q.H.; Le, Y. Efficiency measurement of science and technology resource allocation in China. Stat. Decis. 2020, 36, 46-49. 
15. Shu, T.C.; Nie, X.Q.; Guo, H.W.; Li, X.; Bai, B.J. Analysis of the allocation efficiency of science and technology resources in the Beijing-Tianjin-Hebei urban agglomeration. Res. Sci. Technol. Manag. 2021, 41, 89-96.

16. Ekboir, J.M. Research and technology policies in innovation systems: Zero tillage in Brazil. Res. Policy 2003, 32, 573-586. [CrossRef]

17. Antonella, N. The rise and fall of regional inequalities with technological differences and knowledge spillovers. Reg. Sci. Urban Econ. 2005, 35, 524-569.

18. Guan, Y.; Wu, H.C.; Huang, S. Research on the allocation efficiency of science and technology resources in Jiangsu Province Based on Improved DEA. Sci. Res. Manag. 2011, 32, 145-149.

19. Li, J.X.; Wen, X.N. A study on the relationship between the efficiency of allocation of science and technology financial resources and its influencing factors in China. China Soft Sci. 2019, 34, 164-173. 